\title{
Prevalence and Saverity Level of Scabies (Sarcoptes scabiei) on Rabbits in Sajen Village, Pacet SUB-District, Mojokerto Regency
}

\section{Prevalensi dan Tingkat Keparahan (Sarcoptes scabiei) Pada Ternak Kelinci di Desa Sajen Kecamatan Pacet Kabupaten Mojokerto}

\author{
1)Taufik Tri Laksono, M. ${ }^{2)}$ Gandul Atik Yuliani, ${ }^{3)}$ Agus Sunarso, ${ }^{3)}$ Nunuk Dyah R L, ${ }^{3}$ Lucia Tri \\ Suwanti, ${ }^{4}$ Soeharsono \\ 1) Mahasiswa, ${ }^{2}$ )Departemen Kedokteran Dasar Veteriner, 3)Departemen Parasitologi Veteriner. Fakultas \\ Kedokteran Hewan Universitas Airlangga.
}

\begin{abstract}
Abstrak
Penelitian ini bertujuan untuk mengetahui prevalensi dan tingkat keparahan scabies (Sarcoptes scabiei) pada ternak kelinci di Desa Sajen, Kecamatan Pacet, Kabupaten Mojokereto. Sarcoptes scabiei var. cuniculi merupakan tungau dengan predileksi di stratum korneum dari kulit dan penyebab scabies. Gejala klinis ditandai dengan alopecia and krusta pada kulit. Penelitian ini menggunakan metode penelitian eksploratif labolatorik dengan pendekatan cross sectional. Sampel yang digunakan adalah kelinci pada satu peternakan yang memiliki gejala klinis scabies dan hasil dari kerokan kulit pada pemeriksaan laboratoris secara natif. Kelinci yang positif scabies kemudian dilakukan skoring berdasarkan tingkat keparahan pada regio tubuh dan gejala klinisnya. Hasil penelitian menunjukkan bahwa dari 110 ekor kelinci dalam populasi, terdapat 19 ekor yang terinfeksi scabies dan terdapat 2 tingkat keparahan scabies pada kelinci yaitu tingkat keparahan ringan dan sedang yang terbagi atas 2 regio tubuh. Tingkat keparahan ringan menunjukkan gejala klinis alopecia dan krusta pada regio wajah sedangkan tingkat keparahan sedang pada regio wajah dan kaki. Kesimpulan pada penelitian ini adalah angka prevalensi scabies sebesar $17,27 \%$ dan tingkat keparahan ringan sebesar $26,32 \%$ serta tingkat keparahan sedang sebesar 73,68.
\end{abstract}

Kata kunci : kelinci, prevalensi, tingkat keparahan, scabies, Sarcoptes scabiei.

\section{Pendahuluan}

Scabies adalah penyakit kulit menular yang disebabkan oleh infestasi dari Sarcoptes scabiei. Penyakit ini sering disebut juga dengan kudis (Handoko, 2008). Tungau menyerang dengan cara menginfestasi kulit induk semangnya dan bergerak membuat terowongan di bawah lapisan kulit (stratum korneum dan lusidum) sehingga menyebabkan gatal-gatal, kerontokan rambut, dan kerusakan kulit (Urqurath et al., 1989; Lastuti et al., 2017)

Scabies merupakan penyakit yang banyak menyerang ternak, bahkan manusia (Desiandura et al., 2017). Penularannya dapat terjadi melalui kontak langsung antar hewan penderita bahkan kontak tidak langsung yaitu melalui peralatan yang terkontaminasi (Eleser dkk., 2005). Tingkat hygiene dan sanitasi yang relatif rendah menjadi faktor pemicu terjangkitnya penyakit ini. Kondisi kandang yang sempit, lembab, dan berdesakan semakin mempermudah penularan penyakit scabies dari hewan penderita kepada hewan yang sehat (Partosoedjono, 2003).

Menurut McCarthy et al. (2004) Sarcoptes scabiei ini ditemukan hampir di seluruh dunia. Laporan terhadap outbreak atau kasus scabies pada kelinci juga pernah tercatat. kerugian akibat matinya ternak penderita scabies sangat bervariasi, tergantung pada faktor predisposisi serta faktor lainnya yang terlibat. Kematian akibat scabies sering disebabkan karena malnutrisi (AbuSamra et al., 1981). Kerugian ekonomi yang timbul 
akibat scabies berupa: turunnya produksi (daging, air susu, kulit, wool), turunnya "feed conversion efficiency", kematian penderita dan pembelian obat-obatan serta biaya untuk tenaga kesehatan. Pemakaian obat- obatan untuk mengatasi scabies, seperti terutama akarisida, roborantia seperti vitamin $\mathrm{A}$, mineral, dan untuk mengatasi infeksi sekunder seperti anthelmitika. antibiotika, fungisida, tentunya akan meningkatkan ongkos produksi. Akhirnya menurunkan keuntungan (Putra, 1994).

\section{Metode Penelitian}

Penelitian ini merupakan penelitian cross sectional dengan ekplorasi laboratoris yang selanjutnya akan diuji menggunakan metode chi-square dan korespondensi. Data yang diperoleh akan diolah dengan program SPSS.

Sampel penelitian yang digunakan berupa kelinci yang menunjukkan gejala klinis terinfeksi scabies dan hasil scraping atau kerokan kulit Besar sample dihitung dari jumlah kelinci yang yang menunjukkan gejala klinis scabies dan positif scabies melalui pemeriksaan laboratorium yang menunjukkan adanya tungau Sarcoptes scabiei.

Penelitian ini telah dilakukan di peternakan breeding kelinci yang terletak di Desa Sajen, Kecamatan Pacet, Kabupaten Mojokerto serta pemeriksaan sampel dilakukan di laboratorium Entomologi dan Protozoologi Departemen Parasitologi Fakultas Kedokteran Hewan Universitas Airlangga pada bulan September hingga Desember 2017. Alat yang digunakan dalam penelitian ini berupa sarung tangan, obat antiseptik (alkohol 70\%), kapas, cawan petri, scalpel, pipet atau spuit disposable, obyek glass, cover glass, mikroskop. Bahan pada penelitian ini berupa sampel hasil skraping atau kerokan kulit ditambah $\mathrm{KOH}$ 10\% untuk melarutkan kerakkerak.

Perhitungan prevalensi scabies pada ternak kelinci ini menggunakan rumus prevalence rate. Tingkat keparahan dari masing-masing kelinci yang terduga menderita scabies, harus dilakukan pemeriksaan secara langsung pada setiap ekor kelinci yang menunjukkan gejala klinis scabies berupa krusta dan alopecia pada beberapa regio tubuh.
Tabel 1. Pembagian Grade dan Skor Tingkat Keparahan Scabies

\begin{tabular}{|c|c|c|c|}
\hline Regio tubuh & Gejala klinis & Skor & $\begin{array}{c}\text { Tingkat } \\
\text { keparah } \\
\text { an }\end{array}$ \\
\hline $\begin{array}{l}\text { Regio wajah } \\
\text { (mulut, hidung } \\
\text { mata, dan } \\
\text { telinga) }\end{array}$ & $\begin{array}{l}1.1 \text { Terdapat alopecia } \\
\text {,ringan }(\mathrm{o}-1 \mathrm{~cm}) \\
1.2 \text { Terdapat alopecia } \\
\text { berat }(>1 \mathrm{~cm}) \\
1.3 \text { Terdapat perlukaan } \\
\text { (krusta) }\end{array}$ & $\begin{array}{l}1 \\
2\end{array}$ & Ringan \\
\hline $\begin{array}{l}\text { Regio kaki } \\
\text { (kaki depan } \\
\text { dan kaki } \\
\text { belakang) }\end{array}$ & $\begin{array}{l}2.1 \text { Terdapat alopecia } \\
\text { ringan }(\mathrm{o}-1 \mathrm{~cm}) \\
2.2 \text { Terdapat alopecia } \\
\text { berat }(>1 \mathrm{~cm}) \\
2.3 \text { Terdapat perlukaan } \\
\text { (krusta) }\end{array}$ & $\begin{array}{l}4 \\
5 \\
6\end{array}$ & Sedang \\
\hline \multirow[t]{2}{*}{$\begin{array}{l}\text { Regio badan } \\
\text { (pada area } \\
\text { selain wajah } \\
\text { dan kaki) }\end{array}$} & $\begin{array}{l}3.1 \text { Terdapat alopecia } \\
\text { ringan }(\mathrm{o}-1 \mathrm{~cm}) \\
3.2 \text { Terdapat alopecia } \\
\text { berat }(>1 \mathrm{~cm})\end{array}$ & 7 & Berat \\
\hline & $\begin{array}{l}\text { 3. } 3 \text { Terdapat perlukaan } \\
\text { (krusta) }\end{array}$ & 9 & \\
\hline
\end{tabular}

\section{Hasil dan Pembahasan}

Dari 110 ekor kelinci yang diperiksa secara klinis, ditemukan 19 ekor kelinci dengan gejala klinis pada krusta dan alopecia. Ternak kelinci lainnya yang tidak menunjukkan gejala klinis pada permukaan kulit tidak dilakukan pengerokan pada kulit untuk dilanjutkan dalam pemeriksaan laboratoris sehingga didapatkan angka prevalensi scabies pada ternak kelinci di Desa Sajen, Kecamatan Pacet, Kabupaten Mojokerto sebesar 17,27\%.

Gambaran mikroskopis pada kerokan kulit kelinci menunjukkan gambaran bentuk Sarcoptes scabiei yang tumbuh dan berkembang biak di permukaan kulit kelinci, sehingga menyebabkan penyakit scabies (Gambar 1).

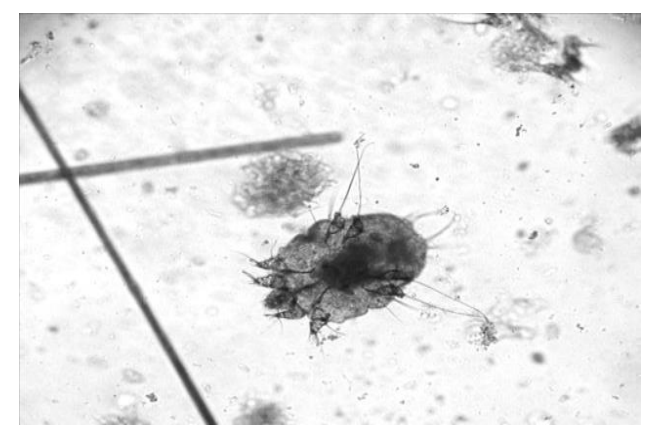

Gambar 1. Tungau Sarcoptes scabiei pada Hasil Pemeriksaan Kerokan Kulit Secara Natif di Bawah Mikroskop dengan Perbesaran 100x. 
Secara morfologi S. scabiei berukuran kecil, berbentuk oval, punggungnya cembung dan bagian perutnya rata. S. scabiei transparan, berwarna putih kotor, dan tidak bermata. Bentuk dewasa mempunyai 4 pasang kaki (Handoko, 2008).
Hasil penilaian tingkat keparahan krusta scabies berdasarkan beberapa komponen seperti distribusi dan luas krusta, ketebalan krusta, riwayat kejadian penyakit, dan kondisi kulit serta presentase krusta scabies berdasarkan pembagian regio tubuh kelinci yang terdapat krusta dan alopecia, pada 19 sampel kelinci didapatkan hasil seperti pada Tabel 2 di bawah ini.

Tabel 2. Hasil Penilaian Tingkat Keparahan Scabies

\begin{tabular}{|c|c|c|c|c|c|}
\hline No. & $\begin{array}{l}\text { Kode } \\
\text { Sampel }\end{array}$ & Regio & $\begin{array}{l}\text { Gejala } \\
\text { Klinis }\end{array}$ & Score/ Nilai & $\begin{array}{l}\text { Tingkat } \\
\text { Keparahan }\end{array}$ \\
\hline \multirow{3}{*}{$\begin{array}{l}1 . \\
2 .\end{array}$} & $\mathrm{K}_{1}$ & 1 & 1.3 & 3 & \multirow{3}{*}{$\begin{array}{l}\text { Ringan } \\
\text { Ringan }\end{array}$} \\
\hline & $\mathrm{K}_{2}$ & 1 & 1.3 & 3 & \\
\hline & $\mathrm{K}_{3}$ & 1 & 1.3 & 3 & \\
\hline 3. & $\mathrm{~K}_{4}$ & 2 & 2.3 & 6 & \multirow[b]{2}{*}{ Sedang } \\
\hline 4 & & 1 & 1.3 & 3 & \\
\hline \multirow[b]{2}{*}{5} & $\mathrm{~K}_{5}$ & 2 & 2.2 & 5 & \multirow{3}{*}{$\begin{array}{l}\text { Sedang } \\
\text { Ringan }\end{array}$} \\
\hline & & 1 & 1.2 & 2 & \\
\hline 6. & K6 & 1 & 1.3 & 3 & \\
\hline 7. & $\mathrm{~K}_{7}$ & 1 & 1.3 & 3 & Ringan \\
\hline \multirow[t]{2}{*}{8.} & K8 & 1 & 1.3 & 3 & \multirow[t]{2}{*}{ Ringan } \\
\hline & $\mathrm{K}_{9}$ & 2 & 2.3 & 6 & \\
\hline \multirow[t]{2}{*}{9.} & & 1 & 1.2 & 2 & \multirow[t]{2}{*}{ Sedang } \\
\hline & $\mathrm{K}_{10}$ & 2 & 2.2 & 5 & \\
\hline 10. & & 2 & 2.2 & 5 & \multirow{2}{*}{$\begin{array}{l}\text { Sedang } \\
\text { Sedang }\end{array}$} \\
\hline \multirow[t]{2}{*}{11.} & $K_{11}$ & 1 & 1.3 & 3 & \\
\hline & $\mathrm{K}_{12}$ & 2 & 2.3 & 6 & \multirow{3}{*}{ Sedang } \\
\hline \multirow[t]{2}{*}{12.} & & 1 & 1.3 & 3 & \\
\hline & $\mathrm{K}_{13}$ & 2 & 2.3 & 6 & \\
\hline \multirow[t]{2}{*}{13.} & & 1 & 1.3 & 3 & \multirow[t]{2}{*}{ Sedang } \\
\hline & $\mathrm{K}_{14}$ & 2 & 2.3 & 6 & \\
\hline \multirow[t]{2}{*}{14.} & & 1 & 1.3 & 3 & \multirow[t]{2}{*}{ Sedang } \\
\hline & $\mathrm{K}_{15}$ & 2 & 2.3 & 6 & \\
\hline \multirow[t]{2}{*}{15.} & & 1 & 1.2 & 2 & \multirow[t]{2}{*}{ Sedang } \\
\hline & $\mathrm{K}_{16}$ & 2 & 2.3 & 6 & \\
\hline \multirow[t]{2}{*}{16.} & & 1 & 1.3 & 3 & \multirow[t]{2}{*}{ Sedang } \\
\hline & $\mathrm{K}_{17}$ & 2 & 2.3 & 6 & \\
\hline 17. & & 2 & 2.2 & 5 & Sedang \\
\hline 18. & $\mathrm{~K}_{18}$ & 1 & 1.1 & 1 & Sedang \\
\hline 19. & $K_{19}$ & 2 & 2.1 & 4 & \\
\hline
\end{tabular}

Presentase tingkat keparahan ringan sebesar $26,32 \%$ dari keseluruhan sampel dan sebesar 73,68\% tergolong pada tingkat keparahan sedang. 


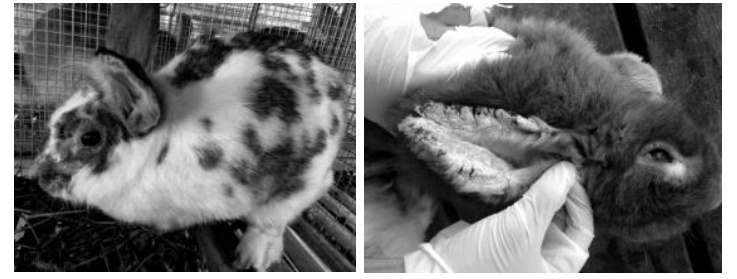

Gambar 2. Kelinci dengan Tingkat Keparahan scabies Ringan.

Gambar 2. menunjukkan kelinci dengan tingkat keparahan scabies yang tergolong ringan. Kelinci dengan tingkat keparahan ini ditemukan gejala klinis berupa alopecia dan krusta pada regio wajah yang meliputi area mulut, hidung, mata dan telinga.

Kelinci dengan tingkat keparahan sedang memiliki gejala klinis berupa alopecia dan krusta pada regio wajah dan kaki yang meliputi kaki depan dan belakang yang dapat dilihat pada Gambar 3 .
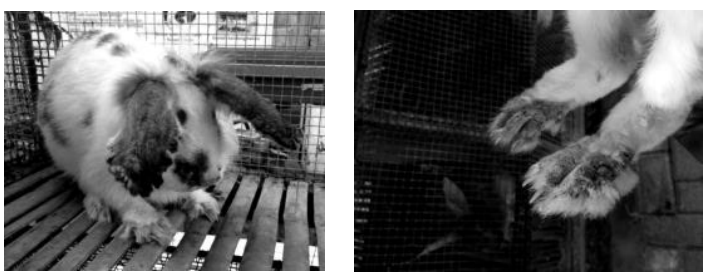

Gambar 3. Kelinci dengan Tingkat Keparahan scabies sedang.

Dari analisis uji chi-square yang sudah dilakukan, didapatkan hasil yaitu tidak ada hubungan antara regio wajah dan kaki serta tingkat keparahan pada masing-masing regio tersebut (Lampiran 2), sedangkan pada hasil uji korespondensi didapatkan bahwa tidak berbeda nyata antara regio dan gejala klinis scabies (Lampiran 3). Perhitungan tingkat keparahan pada Tabel 4.1 menunjukkan jumlah pada grade 1 atau tingkat keparahan ringan sebesar $26,32 \%$ dan grade 2 atau tingkat keparahan sedang sebesar 73,68\%.

Diagnosa yang mengacu pada gejala klinis serta pemeriksaan laboratoris pada penelitian ini digunakan sebagai cara penentuan sampel positif yang selanjutnya akan dihitung dengan rumus prevalence rate. Hasil analisis yang mengacu pada angka prevalensi menunjukkan bahwa data kejadian scabies di Desa Sajen, Kecamatan Pacet, Kabupaten cukup rendah. Hal ini dikarenakan beberapa faktor penyebab terjadi scabies yang cukup beragam.

Pengamatan secara langsung yang dilakukan oleh peneliti menunjukkan bahwa faktor kandang yang meliputi sanitasi/kebersihan, jenis serta letak menjadi faktor utama terjadinya scabies. Kandang dengan jenis individu atau terdapat 1-2 kelinci dalam satu kandang dan berjarak dekat pada masing-masing kelinci akan menyebabkan mudah tertularnya hewan sakit ke sehat. Letak kandang yang secara tidak langsung berhadapan dengan sinar matahari juga menjadi faktor tinggi atau rendahnya kejadian scabies. Pada peternakan kelinci ini didapatkan bahwa letak kandang yang terkena sinar matahari secara tidak langsung akan mengakibatkan rendahnya kejadian scabies dikarenakan kondisi kandang yang tidak lembab serta bersih. Hal ini sesuai dengan pernyataan menurut Jensen dan Swift (2006), sanitasi kandang dan lingkungan yang kurang baik juga diduga menjadi faktor utama penularan penyakit scabies. Kandang terlihat kurang mendapat sinar matahari, akibat keadaan kandang lembab. Tempat yang lembab dapat menyebabkan tungau dapat bertahan hidup lebih dari 30 hari. Menurut Budiantono (2004), kejadian scabies pada ternak telah tersebar luas di seluruh Indonesia, terutama pada keadaan kekurangan pakan dan di lingkungan kandang yang kotor dengan prevalensi 4-11\%.

Berdasarkan gejala klinis yang mencirikan scabies berupa alopecia dan krusta, maka dapat dinilai tingkat keparahan scabies. Penentuan tingkat keparahan scabies berdasarkan hasil skoring/penilaian scabies menurut Davis et al (2013) dari beberapa komponen seperti distribusi dan luas krusta, ketebalan krusta, riwayat kejadian penyakit, dan kondisi kulit serta presentase krusta scabies. Pembagian atas beberapa regio tubuh juga menjadi dasar pengelompokkan tingkat keparahan scabies. Pembagian beberapa regio pada tubuh kelinci meliputi regio wajah, kaki, dan badan. Menurut Percy dan Barthold (2001) pada lagomorpha sejenis kelompok kelinci, tidak umum terjadi infeksi $S$. scabiei (juga dikenal sebagai kudis) dan kudis tersebut menunjukkan pengaruh pada bagian wajah, hidung, bibir, dan genital eksternal.

Pada penelitian ini tidak didapatkan hasil tingkat keparahan berat, hal ini bisa dikaitkan pada pengamatan secara langsung terhadap 
faktor-faktor penyebab scabies. Peternakan kelinci pada penelitian ini tergolong bersih dan dengan manajemen yang baik. Ternak kelinci yang terdiagnosa atau menunjukkan gejala klinis scabies dalam waktu 1-3 hari berikutnya diberi obat melalui injeksi ivermectin sesuai dosis. Sehingga jarang ditemukan ternak kelinci dengan kondisi tingkat keparahan yang berat. Menurut Colville (2000), pada kasus dengan tingkat keparahan berat dapat terlihat gejala klinis yang lain yaitu hewan akan menggesekgesekkan daerah yang gatal ke tiang kandang atau pohon-pohon, menggaruk-garuk atau mencakar dan menggigit kulitnya secara terus-menerus.

Pada hasil uji chi-square menunjukkan bahwa tidak ada hubungan antara regio wajah dan kaki serta tingkat keparahan pada regio tersebut yang dihubungkan dengan gejala klinis scabies. Hal ini berkaitan dengan infeksi parasit yang disebabkan oleh tungau Sarcoptes scabiei menginfeksi tubuh kelinci dapat menyerang bagian manapun. Pada masing-masing regio dapat dilihat pada hasil bahwa gejala klinis yang tampak tidak sama walaupun dalam konsep patogenitas atau tingkatan keparahan scabies

Sedangkan pada uji korespondensi didapatkan hasil yaitu tidak berbeda nyata antara regio dan gejala klinis. Hal ini berhubungan dengan infeksi scabies tidak bisa ditentukan secara langsung lokasinya atau terdapatnya gejala klinis. Pada hasil pembacaan dimension pada gambaran hasil uji korespondensi didapatkan hasil yaitu pada regio kaki lebih banyak terdapat gejala klinis berupa krusta dibandingkan pada regio wajah. Sedangkan gejala klinis berupa alopecia berat dapat ditemukan sama besar kejadiannya pada regio wajah dan kaki.

\section{Kesimpulan}

Angka prevalensi scabies pada ternak kelinci di Desa Sajen, Kecamatan Pacet, Kabupaten Mojokerto adalah sebesar $17,27 \%$. Tingkat keparahan scabies pada ternak kelinci di Desa Sajen, Kecamatan Pacet, Kabupaten Mojokerto terbagi atas 2 yaitu tingkat keparahan ringan dan sedang. Tingkat keparahan ringan terlihat gejala klinis berupa alopecia dan krusta pada regio wajah sedangkan keparahan sedang terlihat gejala klinis berupa alopecia dan krusta pada regio wajah dan kaki. Tingkat keparahan ringan sebesar $26,32 \%$ dan sedang sebesar $73,68 \%$.

\section{Daftar Pustaka}

Abu-Samra, M.T., B.E.D. Hago, M.A. Aziz and F.W. Awad. 1981. Sarcoptic mange in sheep in the Sudan. Annal of Tropical Medicine and Parasitology. 75: 639-645. Percy, D. H. and S. W. Barthold. 2001. Pathology of laboratory rodents and rabbits. Iowa State University Press, Ames, Iowa. 295.

Budiantono. 2004. Kerugian Ekonomi Akibat Scabies Dan Kesulitan Dalam Pemberantasannya. Denpasar: Balai Penyidikan dan Pengujian Veteriner Regional VI.

Colleville, J. 200o. Diagnostic Parasitology for Veterinary Technicians. American

Davis, J. S., McGloughlin, S., Tong, S. Y. C. Walton, S. F., and Currie, B. J. 2013. A Novel Clinical Grading Scale to Guide the Management of Crusted Scabies. PLoS Neglected Tropical Disease. 7(9): e2387.

Eleser, S., Junjungan, J., Manurung dan T., Suibu. 2005. Efektivitas pemberian monolaurin dan obat alternative lainnya dalam memberantas penyakit skabies pada kambing. Pros. Seminar Nasional Peternakan dan Teknologi Veteriner, Bogor, 12-13 September 2005. Puslitbang Peternakan, Bogor. 941-945.

Handoko, R.P. 20o8. Ilmu Penyakit Kulit dan Kelamin. Adhi Djuanda. Fakultas Kedokteran Universitas Indonesia, Jakarta. 5: 122125.

Jensen, R. and B. L. Swift. 2006. Disease of Sheep. 2 years Eds. Lea \& Febiger. Philadelphia. Lastuti, N.D.R., Rantam, F.A., Hastutiek, P., and Chrismanto, D. 2017. Toll Like Receptor (TLRs) play role in adaptive immunity in rabbits immunized by Sarcoptes scabiei proteins.

VMIC conference proceeding in KnE life sci. http://knepublishing.com. [13 Januari 2017].

McCarthy, J.S, D.J. Kemp, S.F Walton and B.J., Currie. 2004. Scabies more than just an irritation. Postgraduate Medical Journal. 8o: 382-387.

Partosoedjono, S. 2003. Scabies dan Kualitas Sanitasi Masyarakat. Kompas, Jumat, 05 September 2003. 65-70. 
Putra, A. A. G. 1994. Kajian epidemiologi dan kerugian ekonomi scabies. Laporan Rapat Koordinasi Kesehatan Hewan Wilayah Nusa Tenggara tanggal 16-18 Nopember 1994. Balai Penyidikan Penyakit Hewan Wilayah VI Denpasar.

Radi, Z.A. 2004. Outbreak of Sarcoptic Mange and Malasseziasis in Rabbits (Oryctolagus cuniculus). Comparative Medicine by the American Association for Laboratory Animal Sci. 54(4): 434-437.
Urquhart, G.M., J . Armaur, H . Duncan, A .M. Doon and F.W. Jenning. 1989. Veterinary Parasitology. Long Man Scientific and Technical. New York. 184 - 187. 